\title{
Rapid Biosynthesis Method and Characterization of Silver Nanoparticles Using Zizyphus spina christi Leaf Extract and Their Antibacterial Efficacy in Therapeutic Application
}

\author{
Eman Mohamed Halawani \\ Faculty of Science, Biology Department, Taif University, Taif, KSA \\ Email: halawani.em@hotmail.com
}

How to cite this paper: Halawani, E.M. (2017) Rapid Biosynthesis Method and Characterization of Silver Nanoparticles Using Zizyphus spina christi Leaf Extract and Their Antibacterial Efficacy in Therapeutic Application. Journal of Biomaterials and Nanobiotechnology, 8, 22-35.

http://dx.doi.org/10.4236/jbnb.2017.81002

Received: November 3, 2016

Accepted: December 12, 2016

Published: December 15, 2016

Copyright $\odot 2017$ by author(s) and Scientific Research Publishing Inc. This work is licensed under the Creative Commons Attribution International License (CC BY 4.0).

http://creativecommons.org/licenses/by/4.0/

c) (i) Open Access

\begin{abstract}
Antibacterial activity of biosynthesized silver nanoparticles (AgNPs) was significant in therapeutic application of nanotechnology. These researchers studied an ecofriendly and rapid method for the first time to synthesize silver nanoparticles using Zizyphus spina christi $L$ aqueous leaves extract (ZSE), and their antibacterial properties. The extract was found to have the potential to form silver nanoparticles at room temperature within few minutes. The green synthesized silver nanoparticles were characterized using different techniques. The UV-visible spectrum of the solution containing AgNPs showed a peak at $414 \mathrm{~nm}$ corresponding to the plasmon absorbance of silver nanoparticles. The transmission electron microscopy (TEM) showed that the formed particles were hexagonal in shape with appreciable Nano size ranging from 21.5 to $59.67 \mathrm{~nm}$. Fourier Transform Infrared Spectroscopy analysis (FTIR) of biosynthesized AgNPs affirmed the role of ZSE as reducing and capping agent of $\mathrm{Ag}^{+}$ions to AgNPs, and X-Ray Diffraction patterns (XRD) showed that they could be indexed as face-centered-cubic structure of silver. Antibacterial activity of AgNPs was determined by well diffusion and micro plate assay methods, showing maximum inhibition zones of $24 \mathrm{~mm}, 23 \mathrm{~mm}, 15 \mathrm{~mm}$ and $17 \mathrm{~mm}$ against Staphylococcus aureus, Acinetobacter sp., Pseudomonas aeruginosa and Escherichia coli respectively. The minimum inhibitory concentration (MIC) and the minimum bactericidal concentration (MBC) results showed that AgNPs had MIC, MBC of 45, $57 \mu \mathrm{g} / \mathrm{mL}, 49,61$ $\mu \mathrm{g} / \mathrm{mL}, 63,90 \mu \mathrm{g} / \mathrm{mL}$ and 59, $82 \mu \mathrm{g} / \mathrm{mL}$ against $S$. aureus, Acinetobacter sp., $P$. aeruginosa and E. coli respectively. Furthermore, the green synthesized AgNPs were loaded on band-aids and screened for antibacterial activity. The AgNPs loaded on band-aids exhibited strong antibacterial effect against multi drug resistant bacteria. These nanoparticles could be used for treating wounds and preparing wound dressing. Such researches are crucial in the demonstration of therapeutic importance of silver nanoparticles in medical application.
\end{abstract}




\section{Keywords}

Silver Nanoparticles, Zizyphus spina christi L, Antibacterial Activity, Therabiotic

\section{Introduction}

Synthesis of nanoparticles has gained great significance during the last few years due to their unique properties and application [1]. Chemical methods are among the most important approaches in metallic nanoparticles synthesis. However, these methods use high cost and toxic reagents as reducing and stabilizing agents [2]. Currently, there is a growing need to develop inexpensive and environmentally friendly nanoparticles synthesis processes that do not use toxic chemicals in the synthesis protocol [3]. Today, synthesis of nanoparticles is carried out mainly on biological systems such as bacteria [4], fungi [5], yeast [6], algae [7] and plant extracts [8]. In microorganism-mediated methods, the synthesis reaction takes a long time $(24-124 \mathrm{~h})$ and the process of sub-culturing cell cultures is time-consuming [9] [10], whereas in plant-mediated methods, reaction time is greatly short and cultivation of microbial cells step is eliminated, also no need to focus on cross contamination as like microbes.

Although biosynthesis of nanoparticles using plant extracts has already been reported in various plants such as neem [11], Aloe vera [12], Cinnamomum camphora [13], Rosa hybride [14] and Mulberry leaf [15], there is still a lot of attention to this field because of the diversity and the high potential of plants as reducing agent in producing nanoparticles with different shapes. There are many solvents used for extracting the plant components for nanoparticles synthesis like methanol [15] ethanol [16], diethyl ether, chloroform, ethyl acetate [17] and water [18] [19] [20]. As the research is focused on eco-friendly and low cost methods for synthesis of nanoparticles, it is always preferable to use water (aqueous solvent) for extraction procedures and preventing the use of toxic chemicals. Moreover, water is high polar solvent and it is very simple to extract the phytochemical compounds from plant leaves into medium. Recently, researchers have reported that the water soluble organic compounds present in the plant leaves extracts are found to be strong reducing agents for nanoparticles synthesis [21]. The water soluble organics and phenolics present in the plant extracts are mainly reducing agents to change silver ions to metallic AgNPs [22]. Phytochemical analyses of Zizyphus spina christi $L$ leaf extract revealed the presence of phenolic, tannins, flavonoids, alkaloids and saponins. These phytochemical compounds in Zizyphus spina christi $L$. are strong reducing agents due to their abundant $\mathrm{OH}$-groups that enhance their antibacterial and antioxidant activity [22].

Hence, this research work is mainly focused on simple process as a green technology using aqueous extract of Zizyphus spina christi $L$ leafs as a first time for the biosynthesis of silver nanoparticles without the usage of hazardous and toxic solvent. The process has several advantages with low cost, compatibility, stability and also has proved their medical application as wound dressing against skin infection pathogen. 


\section{Methodology}

\subsection{Collection, Processing and Preparation of Zizyphus spina christi Leaf Extract}

Fresh leaves of Zizyphus spina christi $L$ were collected from Taif, KSA. The leaves were thoroughly washed under tap water to remove the adhered and then rinsed with Millipore-Milli-Q water. The aqueous leaf extract of Zizyphus spina christi $L$ was prepared as follows: $25 \mathrm{~g}$ of fresh leaves were mixed with $100 \mathrm{~mL}$ of distilled water in a $250 \mathrm{~mL}$ flask and the contents were boiled for $10 \mathrm{~min}$. The components were cooled to room temperature and filtered through Whatman No. 1 filter paper. The clear leaf extract of Zizyphus spina christi $L$ thus obtained was used for synthesis of silver nanoparticles.

\subsection{Synthesis of Silver Nanoparticles}

Ten milliliter of 25\% Zizyphus spina christi $L$ aqueous extract (ZSE) was gradually added into $90 \mathrm{ml}$ of $1 \mathrm{mM}$ silver nitrate $\left(\mathrm{AgNO}_{3}\right)$ in a $250 \mathrm{ml}$ Erlenmeyer flask and incubated at room temperature with shacking under dark conditions. The reaction solution was checked for 30 minutes and monitoring the change in color of $\mathrm{AgNO}_{3}$ solution from colorless to brown. The AgNPs solution was centrifuged at 15,000 g for at least 30 min. The supernatant was discarded and obtained pellet was redispersed in deionized water. The centrifugation for pellet was repeated two to three times to wash off any substances on the surface of silver nanoparticles.

\subsection{Characterization of AgNPs}

\subsubsection{UV-Vis Spectra Analysis}

Analysis of UV-Vis spectra was done by using a double beam spectrophotometer (Shimadzu uv-1650 pc spectrophotometer) [23]. The solution of silver nanoparticles was monitored by measuring the UV-Vis spectrum of the reaction solution in the 300 - 900 $\mathrm{nm}$ wavelength rang after diluting a small aliquot of the solution into deionized water. The solution was pipetted into a test tube and diluted four times by deionized water and analyzed at room temperature.

\subsubsection{Transmission Electron Microscope (TEM)}

The AgNPs was analyzed by using transmission electron microscope (JEOL 100CX II with an accelerating voltage of $100 \mathrm{kV}$, Japan). Silver nanoparticles for TEM analysis was prepared by coating of aqueous solution of AgNPs drops on carbon-coated copper grids, and left to dry for $5 \mathrm{~min}$; the extra solution was removed using blotting paper at room temperature [24].

\subsubsection{Fourier Transform Infrared Spectroscopy (FT-IR)}

Analysis of FT-IR spectra were recorded in the $4000-400 \mathrm{~cm}^{-1}$ with a Shimadzu IR-470 Spectrometer (Shimadzu, Japan), equipped with data station. Dried samples of about $100 \mathrm{mg}$ were mixed with $100 \mathrm{mg}$ of spectral grade $\mathrm{KBr}$ and pressed into discs under hydraulic pressure [25].

\subsubsection{X-Ray Diffraction (XRD)}

$\mathrm{X}$-ray diffraction analysis was detected to examine the crystallographic structure of the 
purified AgNPs [26]. The XRD grids were coated with dried biosynthesized nanoparticles and the synthesized nanoparticles diffraction pattern was measured by X-ray diffractometer (Shimadzu XD-3A).

\subsection{Antibacterial Activity}

\subsubsection{Determination of Antibacterial Activity of AgNPs}

The AgNPs and aqueous extract prepared by Zizyphus spina christi $L$ were used to evaluate antimicrobial activity against Gram positive bacteria, Staphylococcus aureus (S. aureus) and Gram negative bacteria, Echerichia coli (E. coli), Acinetobacter $s p$, and Pseudomonas aeruginosa ( $P$. aeruginosa) on Mueller Hinton Agar plates by agar well diffusion method [27]. The Minimum Inhibitory Concentration (MIC) and Minimal Bactericidal Concentration (MBC) methods for all test bacterial strains were also determined using micro plate assay method.

\subsubsection{Antimicrobial Activity of AgNPs-Band Aids}

One hundred microliter of AgNPs was added on the sterilized band aids of $1 \mathrm{~cm}^{2}$ under sterilized condition. The band aids was kept at $50^{\circ} \mathrm{C}$ for overnight to evaporate the excess water content and tested against the four multidrug resistant pathogenic bacteria (S. aureus, Acinetobacter sp., P. aeruginosa and E. coli). The pathogenic bacteria were spread on Mueller Hinton Agar plates and AgNPs-band aids were placed on the surface of agar. The petri dishes were then incubated at $37^{\circ} \mathrm{C}$ for 24 hours. Finally, the zone of inhibition was determined.

\section{Results and Discussion}

\subsection{Biosynthesis of AgNPs}

The formation of silver nanoparticles was monitored with color change and UV-Vis spectroscopy. The biosynthesis of AgNPs was prepared using $90 \mathrm{ml}$ of $\mathrm{AgNO}_{3}$ solution and $10 \mathrm{ml}$ of Zizyphus spina christi $L$ leaf extract $25 \%$. Change in color of solution from colorless to deep brown was observed for the formation of silver nanoparticles in the solution after $30 \mathrm{~min}$ of incubation at room temperature and shaking condition (Figure 1), indicating the formation of AgNPs [28].

\subsection{Characterization of Silver Nanoparticles}

\subsubsection{UV-Vis Spectra Analysis}

Noble metals are known to display unique optical properties due to the property of surface plasmon resonance (SPR). The reduction of $\mathrm{AgNO}_{3}$ to silver nanoparticles by the leaf extract of Zizyphus spina christi $L$ was confirmed by measuring the UV-Vis spectrum of the solution. The silver nitrate solution $(1 \mathrm{mM})$ was added to the aqueous leaves extract (25\%). This change of color was due to the reduction of $\mathrm{Ag}^{+}$to $\mathrm{Ag}^{0}$ via the active biomolecules present in the leaves extract such as alcohol, phenols polysaccharide and protein [28]. On the other hand higher extract concentrations of the biomolecules act as reducing agent and cap the nanoparticle surfaces and protect them from aggregation. Similar studies showed that a different component in the extract is responsible for the synthesis of symmetrical nanoparticles [28] [29]. The brown color is caused to the excitation of surface plasmon resonance (SPR). As shown in Figure 2, a 
characteristic and well-defined SPR band for silver nanoparticles was comfirmed at around $\lambda=414 \mathrm{~nm}$. The absorption band was constant for more than 3 months which substantiated the stability of the nanoparticles (data not shown).

\subsubsection{Transmission Electron Microscope (TEM)}

The size and morphology of AgNPs were studied by the transmission electron microscopy (TEM) images, by using the JEOL TEM 100 CXII with an accelerating voltage of $120 \mathrm{kV}$ (Electron Microscope Unit, Assiut University, Egypt). The TEM grids were prepared by placing a drop of the reduced solution on a carbon-coated copper grid and by later drying it in air. Smaller sized mixture of tringle and cubic shape nanoparticles were obtained at the operational temperature. There is a variation in particle sizes from 21.5 to $59.67 \mathrm{~nm}$ (Figure 3). These particles were separated and are not aggregated. These small-sized nanoparticles were able to penetrate across the membrane [30] [31] [32]. It was evident that the silver nanoparticles edges were brighter than the center of the nanoparticles, suggesting the particles were encapsulated by biomolecules such as proteins in the Ziziphus leaf extract as confirmed by other studies [29] [30] [31] [32] [33].

\subsubsection{XRD Analysis}

The crystalline of silver nanoparticles was confirmed by the analysis of XRD pattern.

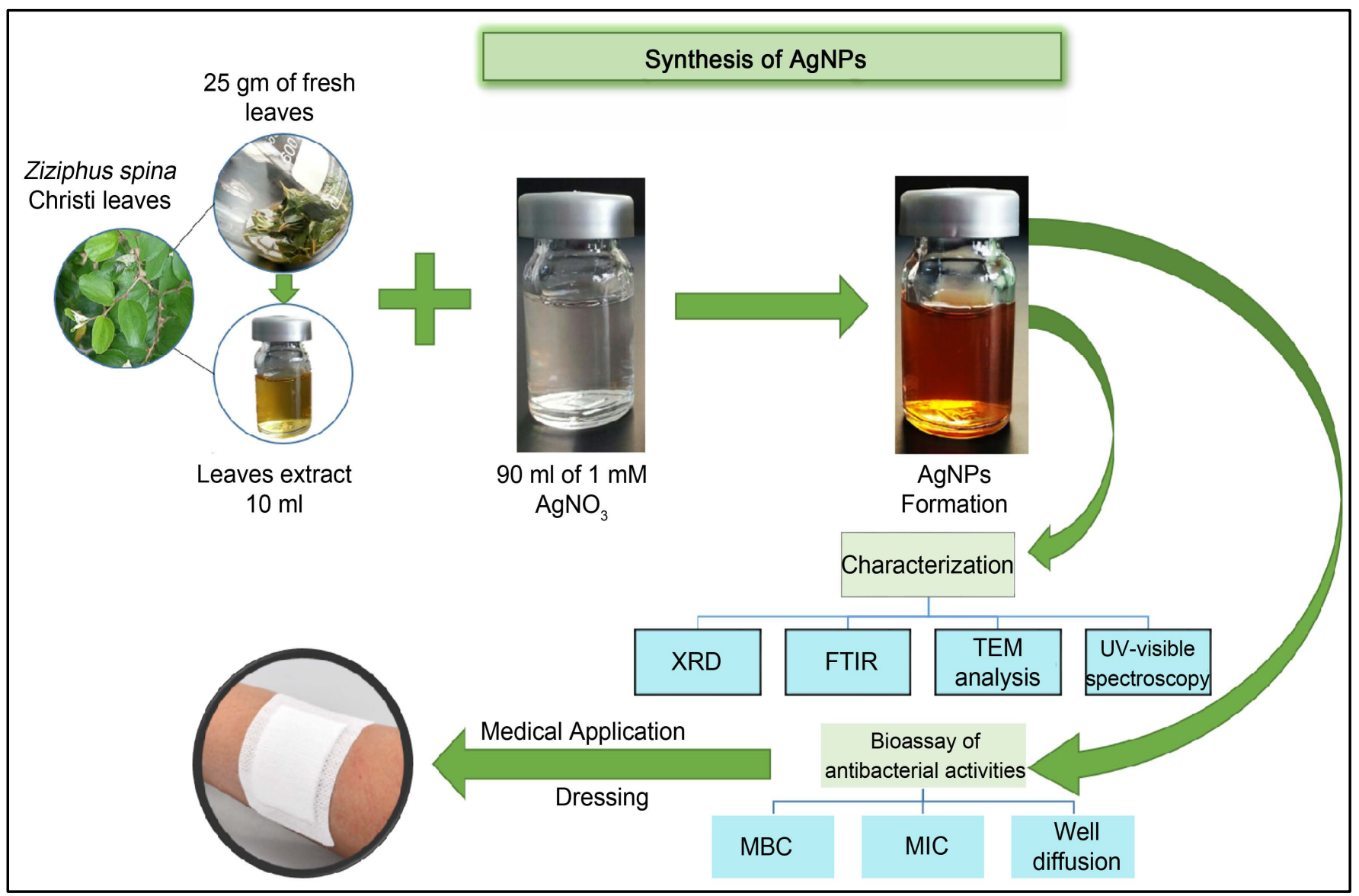

Figure 1. Schematic presentation for biosynthesis, characterization and biomedical applications of synthesized silver nanoparticles using Zizyphus spina-christi L aqueous extract. 


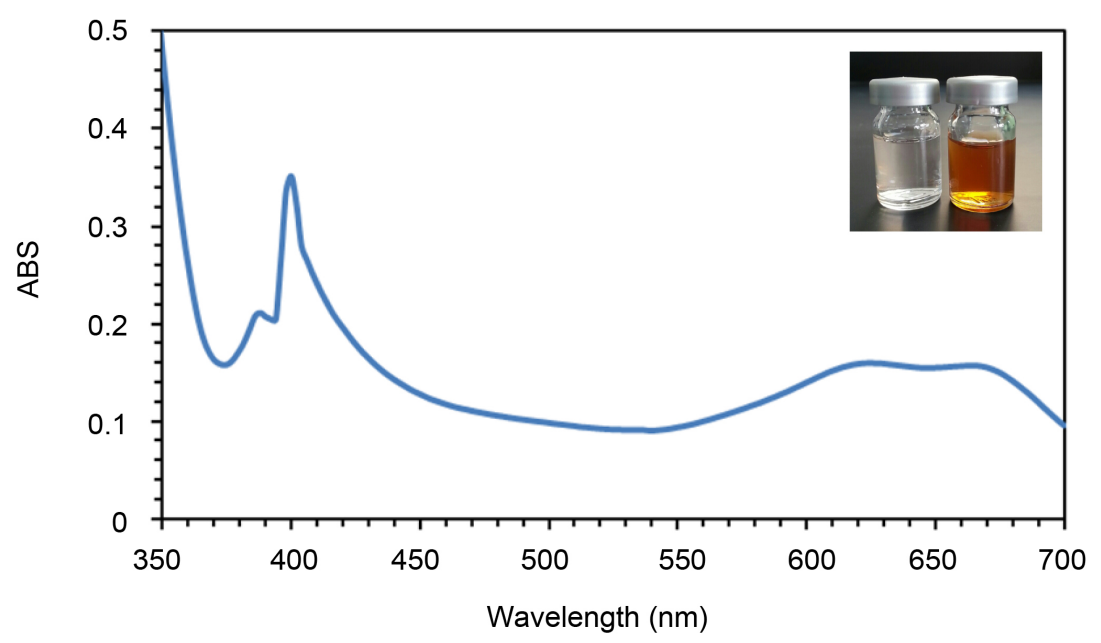

Figure 2. UV-vis spectra of AgNPs $\left(90 \mathrm{ml} 10^{-3} \mathrm{M} \mathrm{AgNO}_{3}\right.$ and $10 \mathrm{ml}$ Zizyphus spina christi $L$ leaf extract $25 \%)$.

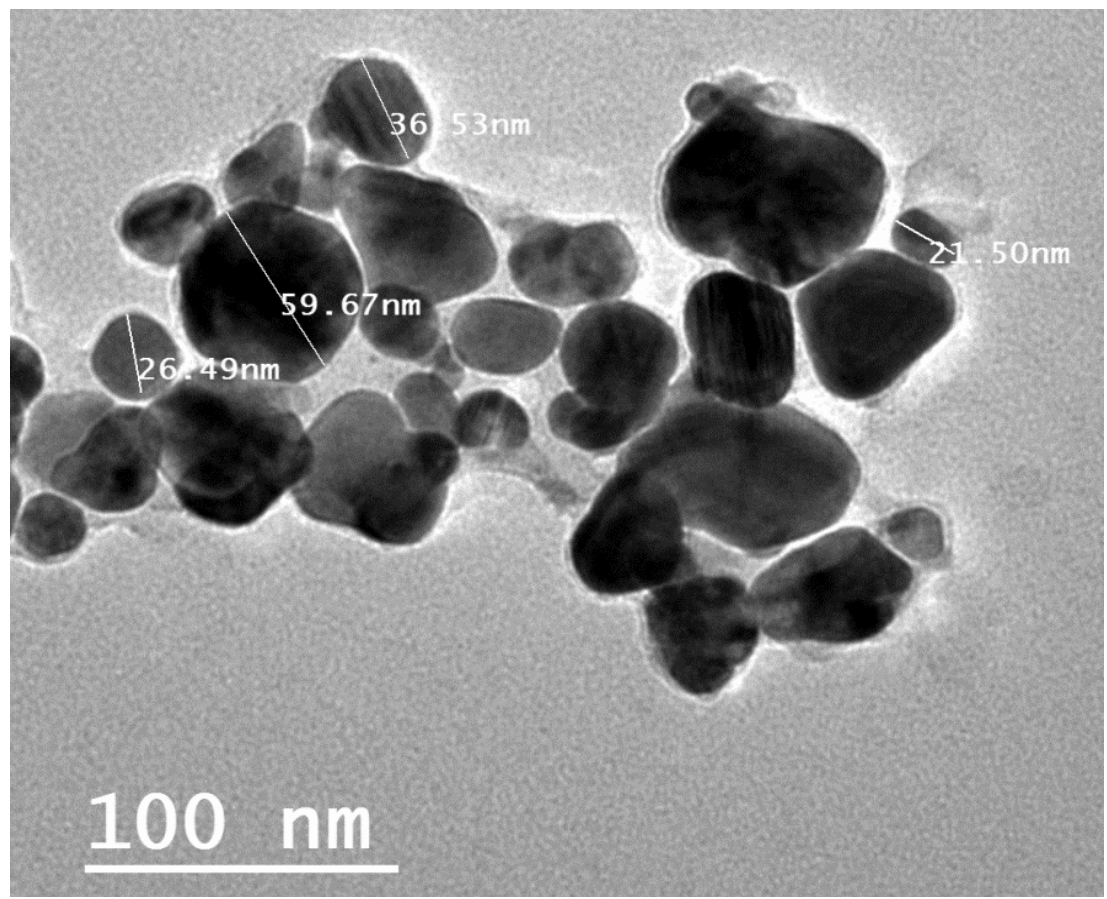

Figure 3. TEM micrograph of the silver nanoparticles after bioreduction $\mathrm{Ag}^{+}$to $\left.\mathrm{Ag}^{0}\right)$ by Zizyphus spina christi.

Figure 4 shows typical XRD pattern of the AgNPs prepared with 25\% Zizyphus spina christi $L$ extract and the $\mathrm{AgNO}_{3}$ concentration $1 \mathrm{mM}$. Many distinct diffraction peaks at approximately $38.09^{\circ}, 46.11^{\circ}, 64.51^{\circ}$ and $74.77^{\circ}$ were assigned to reflections from the 2 theta region, corresponding to (111), (200), (220), and (311) planes of silver respectively. This confirms the basis that they can be displayed as tringle and face-centered-cubic (FCC) structures of silver; it suggested that the synthesized silver nanoparticles were biphas in nature [29]. Additional peaks were also observed at $32.15^{\circ}, 54.73^{\circ}$, and $57.41^{\circ}$. They are apparent in many works in which the XRD pattern included the relevant $2 \theta$ range. These peaks were due to the organic compounds that were present the extract 


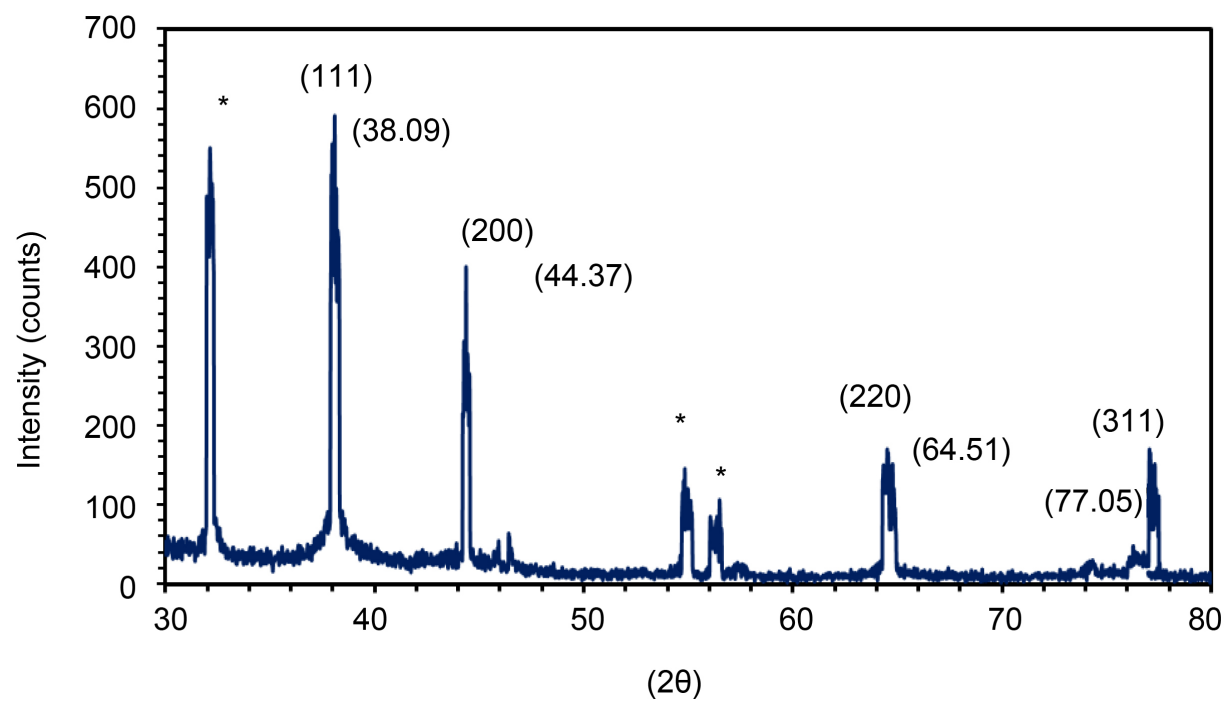

Figure 4. X-ray diffraction pattern of Ag nanoparticles prepared with aqueous Zizyphus spina christi $L$ extract, * Peaks reveal to organic compound of extract.

and responsible for silver ions reduction and stabilization of resultant nanoparticles, similar results were reported earlier [33].

\subsubsection{Fourier Transform Infrared Spectroscopy (FTIR)}

FT-IR analysis measurements were carried out to identify the possible biomolecules responsible for the reduction of the $\mathrm{Ag}^{+}$ions and the capping of AgNPs synthesized by the extract of Zizyphus spina christi L. The solution after complete reduction was centrifuged at 15,000 rpm for 10 minutes to isolate the AgNPs free from the compounds present in the solution. FTIR spectrum of biosynthesized AgNPs showed absorption peaks at $3451.58,2929.981,1600.95$ and $1380.80 \mathrm{~cm}^{-1}$ (Figure 5). Strong absorption peak at $3451.58 \mathrm{~cm}^{-1}$ was resulted from stretching of the $\mathrm{O}-\mathrm{H}$ groups due to the presence of alcohols, phenols, carbohydrates, and etc., while the peak of $1380.80 \mathrm{~cm}^{-1}$ indicating to carboxyl groups. Some works observed modification of these bands after silver recovery with inactivated plant tissue, plant extract and living plant, depend on the natural biomolecules in plants [32] [34]. The variations of the hydroxyl and carboxylate groups have been reported in the several studies on synthesis of AgNPs with another polysaccharide [35] [36]. The peak that appeared around $2921 \mathrm{~cm}^{-1}$ is related to the stretching of the $\mathrm{C}-\mathrm{H}$ bonds [37]. The peak at around $1600 \mathrm{~cm}^{-1}$ was assigned to the amide I bonds (NH) of proteins. Additional absorption peaks at 1727.222 and 1075.71 $\mathrm{cm}^{-1}$ were influenced by the presence of the AgNPs.

\subsection{Antimicrobial Assay}

The antibacterial effect of biosynthesized AgNPs was studied against multi drug resistant (MDR) bacteria in gram positive ( $S$. aureus) and gram negative (E. coli, $P$. aeruginosa and Acinetobacter sp.) bacteria, and AgNPs synthesized by Zizyphus spina christi $L$ displayed excellent antibacterial activity against all tested bacterial strains at the volume of $100 \mu \mathrm{L} /$ well $(9 \mu \mathrm{g})$. AgNPs synthesized by Zizyphus spina christi $L$ showed zone of inhibition range from $15-24 \mathrm{~mm}(17 \mathrm{~mm}$ for E. coli, S. aureus $24 \mathrm{~mm}, P$. aeruginosa 
$15 \mathrm{~mm}$, and $23 \mathrm{~mm}$ for Acinetobacter sp.) (Figure 6 and Table 1). There is no inhibition zone around the well filled with $1 \mathrm{mM} \mathrm{AgNO}_{3}$ and this indicates the antimicrobial activity is due to biosynthesized silver nanoparticles which were known to have strong antimicrobial activity. The antibacterial activity of AgNPs using this medicinal plant demonstrated that both Gram positive and Gram negative bacteria were inhibited. These results agreed with previous work carried out by Hungund et al. [38], Thomas et al. [39], and Chitra and Annadurai [40].

The AgNPs impregnated on band aids were tested against previous bacteria, and inhibition zone was recorded. Band aids with AgNPs showed inhibition zone of $19 \mathrm{~mm}$, $18 \mathrm{~mm}, 15 \mathrm{~mm}$ and $16 \mathrm{~mm}$ for $S$. aureus, Acinetobacter sp., P. aeruginosa and E. coli,

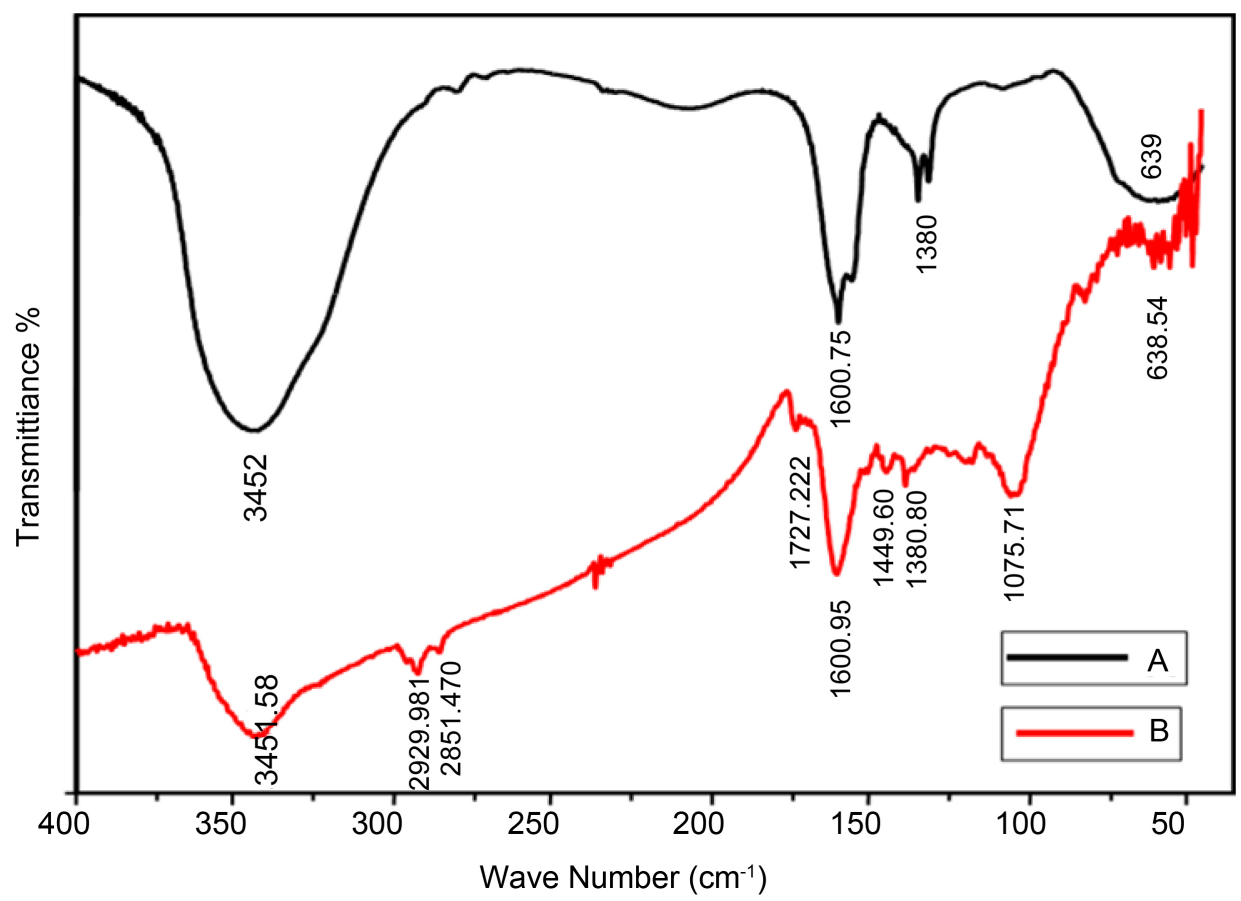

Figure 5. FTIR spectra of Zizyphus spina christi L leaves extract (A) and capped AgNPs (B).

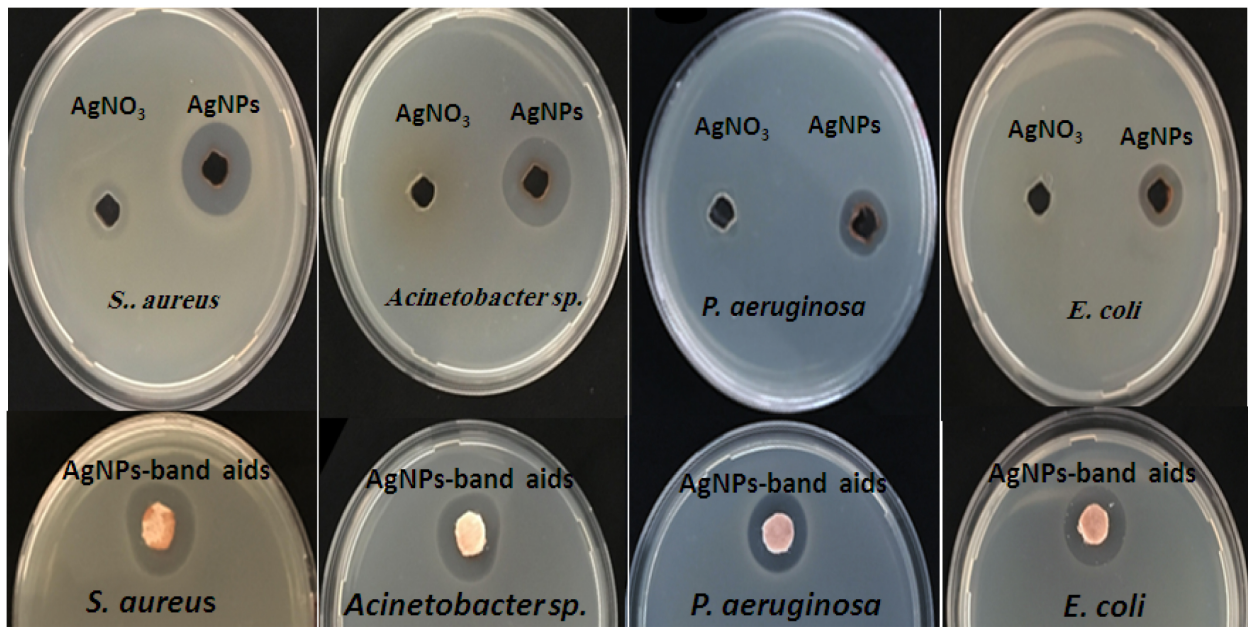

Figure 6. Antibacterial activity of $\mathrm{AgNO}_{3}, \mathrm{AgNPs}$ and AgNPs-band aids against MDR strains of $S$. aureua, Acinetobacter sp., $P$. aeruginosa and $E$. coli patients. 
respectively. The efficacy of band aids with AgNPs against pathogens is given in Figure 6 \& Table 1, these band aids with antibacterial efficiency of AgNPs can be used as an antiseptic bandage material for wound dressing against antibiotic-resistant bacteria Gram-positive and Gram-negative was confirmed in our results. Our study was in agreement with Balashanmugam and Kalaichelvan who reported a high antibacterial activity of green synthesis silver nanoparticles on cotton cloth [41].

The MIC of AgNPs from Zizyphus spina christi $L$ leaves extract was found to be 46, 48, 63 and $59 \mu \mathrm{g} / \mathrm{ml}$ against $S$. aureus, Acinetobacter sp., P. aeruginosa and E. coli strains. Also the MBC of AgNPs from Zizyphus spina christi $L$ leaves extract was found to be 57, 61, 91 and $82 \mu \mathrm{g} / \mathrm{ml}$ against $S$. aureus, Acinetobacter sp., $P$. aeruginosa and $E$. coli strains (Table 2). These findings support the previous reports of antibacterial activity of silver nanoparticles against $S$. aureus MRSA, Acinetobacter, $P$. aeruginosa and E. coli [42] [43] [44].

In our study, Biosynthesized AgNPs with small size exhibited strong antibacterial activity against tested bacteria. Previous researches showed that antibacterial activity of AgNPs depended on size of nanoparticles [45] [46]. Smaller nanoparticles were found to be optimal against pathogenic bacteria [47]. These nanoparticles exhibited superior ability to penetrate bacteria, interact with membrane and cause damage which may lead to cell death, also silver nanoparticles can be uncouple respiratory electron transport from oxidative phosphorylation, which inhibits respiratory chain enzymes and DNA damage [44] [45] [46] [47] [48]. The results displayed tringle and cubic AgNPs which exhibited highest antibacterial activity, this finding was agreeing with other studies [49]. S. aureus was more sensitive to AgNPs than others bacteria used in this study while $P$. aeuginosa was more resistant to AgNPs than others bacteria. For example, MBC of AgNPs against $P$. aeuginosa was $90 \mu \mathrm{g} / \mathrm{ml}$ while it was $57 \mu \mathrm{g} / \mathrm{ml}$ against $S$. aureus (Table 2), so there were difference in minimum bactericidal concentration of

Table 1. Diameter of zone of inhibition by biosynthesized AgNPs \& AgNPs-cloth against Multi drug resistant pathogenic bacteria.

\begin{tabular}{ccc}
\hline Strains & ZOI $(\mathrm{mm})$ by AgNPs & ZOI $(\mathrm{mm})$ by AgNPs-band aids \\
\hline S. aureus & 24 & 1 \\
Acinetobacter sp. & 23 & 18 \\
P. aeruginosa & 15 & 15 \\
E. coli & 17 & 16 \\
\hline
\end{tabular}

ZOI: Zone of Inhibition.

Table 2. The minimum inhibitory concentration of AgNPs (MIC) and Minimal Bactericidal Concentration $(\mathrm{MBC})$ toward Multi drug resistant bacteria.

\begin{tabular}{ccc}
\hline Strains & MIC $(\mu \mathrm{g} / \mathrm{ml})$ & MBC \\
\hline S. aureus & 45 & 57 \\
Acinetobacter $s p$ & 49 & 61 \\
P. aeruginosa & 63 & 90 \\
E. coli & 59 & 82 \\
\hline
\end{tabular}


AgNPs against different bacteria isolate, that means the antibacterial activity of AgNPs depend on the concentration of AgNPs against each bacteria and this was agreement with previous studies [50] [51]. The antibacterial activity of silver nanoparticles could be related to several Factors (size, shape and concentration of MIC and MBC) and we take that in our consideration during synthesis of nanoparticle for clinical use.

Finally, this simple and rapid process for the biosynthesis of silver nanoparticles using aqueous extract of $Z$. spina christi, hemonstrated several advantages with low cost and compatibility for the bioorganic compound capped AgNPs to be used against multi drug resistant bacteria in medical filed.

\section{Conclusion}

The present work was focused on the development of a green, rapid and simple method for the synthesis of AgNPs using Saudi medicinal plant. Silver nanoparticles prepared in this process were fast, low cost, eco-friendly, and could be potentially applied in variety of solutions for different safe medical application. Biosynthesis of silver nanoparticles using Zizyphus spina christi $L$ was prepared by rapid method within 30 mints; the XRD analysis confirmed that the synthesized AgNPs had a face centered cubic phase (fcc). TEM analysis showed that the nanoparticles were hexagonal in shape with different size ranging from 21.5 to $59.67 \mathrm{~nm}$ under optimum conditions. The biomolecules analysis showed that alcohols, phenols, polysaccharides and proteins were important for biosynthesis of AgNPs as active molecules dissolved in water extract of Zizyphus spina christi. Moreover, the synthesized AgNPs and their incorporation in band-aids enhanced the therapeutic efficacy of band and promoted a very good wide spectrum antibacterial material as bioactive band for wound dressing, especially against multi drug resistant bacteria.

\section{References}

[1] Prabhu, S. and Poulose, E. (2012) Silver Nanoparticles: Mechanism of Antimicrobial Action, Synthesis, Medical Applications, and Toxicity Effects. International Nano Letters, 2, 32. https://doi.org/10.1186/2228-5326-2-32

[2] Haider, A. and Kang, I. (2015) Preparation of Silver Nanoparticles and Their Industrial and Biomedical Applications. A Comprehensive Review. Advances in Materials Science and Engineering, 2015, Article ID: 165257. https://doi.org/10.1155/2015/165257

[3] Philip, D., Unni, C., Aromal, S. and Vidhu, V. (2011) Murraya koenigii Leaf-Assisted Rapid Green Synthesis of Silver and Gold Nanoparticles. Spectrochimica Acta Part A: Molecular and Biomolecular Spectroscopy, 78, 899-904. https://doi.org/10.1016/j.saa.2010.12.060

[4] Rajashree, S. and Suman, T. (2012) Extracellular Biosynthesis of Gold Nanoparticles Using a Gram-Negative Bacterium Pseudomonas fluorescens. Asian Pacific Journal of Tropical Disease, 2, S796-S799. https://doi.org/10.1016/S2222-1808(12)60267-9

[5] Mishraa, A., Tripathy, S. and Yun, S. (2012) Fungus Mediated Synthesis of Gold Nanoparticles and Their Conjugation with Genomic DNA Isolated from Escherichia coli and Staphylococcus aureus. Process Biochemistry, 47, 701-711. https://doi.org/10.1016/j.procbio.2012.01.017

[6] Sathish, K., Amutha, R., Arumugam, P. and Berchmans, S. (2011) Synthesis of Gold Nanoparticles: An Ecofriendly Approach Using Hansenula anomala. ACS Applied Materials Interfaces, 3, 1418-1425. https://doi.org/10.1021/am200443j 
[7] Rajeshkumar, S., Malarkodi, C., Gnanajobitha, G., Paulkumar, K., Vanaja, M., Kannan, C. and Annadurai, G. (2013) Seaweed-Mediated Syntheses of Gold Nanoparticles Using Turbinaria conoides and Its Characterization. Journal of Nanostructure in Chemistry, 3, 44-49. https://doi.org/10.1186/2193-8865-3-44

[8] Krishnaraj, C., Jagan, E.G., Rajasekar, S., Selvakumar, P., Kalaichelvan, P.T. and Mohan, N. (2010) Synthesis of Silver Nanoparticles Using Acalypha indica Leaf Extracts and Its Antibacterial Activity against Water Borne Pathogens. Colloids and Surfaces B: Biointerfaces, 76, 50-56. https://doi.org/10.1016/j.colsurfb.2009.10.008

[9] Zaki, S., ElKady, M., Farag, S. and Abd-El-Haleem, D. (2012) Determination of the Effective Origin Source for Nanosilver Particles Produced by Escherichia coli Strain S78 and Its Application as Antimicrobial Agent. Materials Research Bulletin, 47, 4286-4290. https://doi.org/10.1016/j.materresbull.2011.06.025

[10] Correa-Lianten, D.N., Munoz-Ibacache, S.A., Castro, M.E., Munoz, P.A. and Blamey, J.M. (2013) Gold Nanoparticles Synthesized by Geobacillus sp. Strain ID17 a Thermophilic Bacterium Isolated from Deception Island, Antarctica. Microbial Cell Factories, 12, 75-80. https://doi.org/10.1186/1475-2859-12-75

[11] Shankar, S., Rai, A., Ahmad, A. and Sastry, M. (2004) Rapid Synthesis of Au, Ag, and Bimetallic Au Core-Ag Shell Nanoparticles Using Neem (Azadirachta indica) Leaf Broth. Journal of Colloid and Interface Science, 275, 496-502. https://doi.org/10.1016/j.jcis.2004.03.003

[12] Mubarak, A., Thajuddin, N., Jeganathan, K. and Gunasekaran, M. (2011) Plant Extract Mediated Synthesis of Silver and Gold Nanoparticles and Its Antibacterial Activity against Clinically Isolated Pathogens. Colloids and Surfaces B: Biointerfaces, 85, 360-365. https://doi.org/10.1016/j.colsurfb.2011.03.009

[13] Huang, J., Li, Q., Sun, D., Lu, Y., Su, Y., Yang, X., Wang, H., Wang, Y., Shao, W., He, N., Hong, N.J. and Chen, C. (2007) Biosynthesis of Silver and Gold Nanoparticles by Novel Sundried Cinnamomum camphora Leaves. Nanotechnology, 18, 105104-105115. https://doi.org/10.1088/0957-4484/18/10/105104

[14] Noruzi, M., Zare, D., Khoshnevisan, K. and Davoodi, D. (2011) Rapid Green Synthesis of Gold Nanoparticles Using Rosa hybrida Petal Extract at Room Temperature. Spectrochimica Acta Part A: Molecular and Biomolecular Spectroscopy, 79, 1461-1465. https://doi.org/10.1016/j.saa.2011.05.001

[15] Adavallan, K. and Krishnakumar, N. (2014) Mulberry leaf Extract Mediated Synthesis of Gold Nanoparticles and Its Anti-Bacterial Activity against Human Pathogens. Advances in Natural Sciences: Nanoscience and Nanotechnology, 5, Article ID: 025018. https://doi.org/10.1088/2043-6262/5/2/025018

[16] Im, A.R., Han, L., Kim, E.R., Kim, J., Kim, Y.S. and Park, Y. (2012) Enhanced Antibacterial Activities of Leonuri herba Extracts Containing Silver Nanoparticles. Phytotherapy Research, 26, 1249-1255. https://doi.org/10.1002/ptr.3683

[17] Singh, P.K. and Kundu, S. (2013) Biosynthesis of Elixir of Life (Gold Nanoparticles) from Plants. Journal of Environmental Nanotechnology, 2, 52-62.

[18] Prathna, T., Chandrasekaran, N., Raichur, A. and Mukherjee, A. (2011) Biomimetic Synthesis of Silver Nanoparticles by Citrus limon (Lemon) Aqueous Extract and Theoretical Prediction of Particle Size. Colloids and Surfaces B: Biointerfaces, 82, 152-159. https://doi.org/10.1016/j.colsurfb.2010.08.036

[19] Khalil, M., Ismail, E. and Magdoub, F. (2012) Biosynthesis of Au Nanoparticles Using Olive Leaf Extract: 1st Nano Updates. Arabian Journal of Chemistry, 5, 431-437. https://doi.org/10.1016/j.arabjc.2010.11.011

[20] Majumdar, R., Bag, B.G. and Maity, N. (2013) Acacia nilotica (Babool) Leaf Extract Me- 
diated Size-Controlled Rapid Synthesis of Gold Nanoparticles and Study of Its Catalytic Activity. International Nano Letters, 3, 53. https://doi.org/10.1186/2228-5326-3-53

[21] Arunachalam, K. and Annamalai, S. (2013) Chrysopogon zizanioides Aqueous Extract Mediated Synthesis, Characterization of Crystalline Silver and Gold Nanoparticles for Biomedical Applications. International Journal of Nanomedicine, 8, 2375-2384. https://doi.org/10.2147/IJN.S44076

[22] Kumar, G., Sangita, M., Bappadity, M. and Kiran, M. (2011) Phytochemical Evaluvation of Methanolic Extract of Zizyphus xylopyrus. International Journal of Drug Discovery and Herbal Research, 1, 231-233.

[23] Tajdidzadeh, M., Azmi, B.Z., Yunus, W.M., et al. (2014) Synthesis of Silver Nanoparticles Dispersed in Various Aqueous Media Using Laser Ablation. The Scientific World Journal, 2014, Article ID: 324921, 7 p.

[24] Devi, L.S. and Joshi, S.R. (2015) Ultrastructures of Silver Nanoparticles Biosynthesized Using Endophytic Fungi. Journal of Microscopy and Ultrastructure, 3, 29-37. https://doi.org/10.1016/j.jmau.2014.10.004

[25] Yousef, N.M.H. (2014) Characterization and Antimicrobial Activity of Silver Nanoparticles Synthesized by Rice Straw Utilizing Bacterium (Lysinibacillus fusiformis). International Journal of Development Research, 4, 1875-1879.

[26] Moharram, A.H., Mansour, S.A., Hussein, M.A. and Rashad, M. (2014) Direct Precipitation and Characterization of $\mathrm{ZnO}$ Nanoparticles. Journal of Nanomaterials, 2014, Article ID: 716210, $5 \mathrm{p}$.

[27] Sharma, G., Dut Jasuja, N., Rajgovind, Singhal, P. and Joshi, S.C. (2014) Synthesis, Characterization and Antimicrobial Activity of Abelia grandiflora Assisted AgNPs. Journal of Microbial \& Biochemical Technology, 6, 274-278.

[28] Lu, F., Gao, Y., Huang, J., Sun, D. and Li, Q. (2014) Roles of Biomolecules in the Biosynthesis of Silver Nanoparticles: Case of Gardenia jasminoides Extract. Chinese Journal of Chemical Engineering, 22, 706-712. https://doi.org/10.1016/S1004-9541(14)60086-0

[29] Ibrahim, H.M.M. (2015) Green Synthesis and Characterization of Silver Nanoparticles Using Banana Peel Extract and Their Antimicrobial Activity against Representative Microorganisms. Journal of Radiation Research and Applied Sciences, 8, 265-275. https://doi.org/10.1016/j.jrras.2015.01.007

[30] Mallikarjuna, K., Sushma, J.N., Narasimha, G., Manoj, L. and Raju, B.D.P. (2014) Phytochemical Fabrication and Characterization of Silver Nanoparticles by Using Pepper leaf Broth. Arabian Journal of Chemistry, 7, 1099-1103. https://doi.org/10.1016/j.arabjc.2012.04.001

[31] Agnihotri, S., Mukherji, S. and Mukherji, S. (2014) Size-Controlled Silver Nanoparticles Synthesized over the Range 5 - $100 \mathrm{~nm}$ Using the Same Protocol and Their Antibacterial Efficacy. RSC Advances, 4, 3974-3983. https://doi.org/10.1039/C3RA44507K

[32] Haider, A. and Kang, I. (2015) Preparation of Silver Nanoparticles and Their Industrial and Biomedical Applications: A Comprehensive Review. Advances in Materials Science and Engineering, 2015, Article ID: 165257.

[33] Roopan, S.M., Madhumitha, R.G., Rahuman, A.A., Kamaraj, C., Bharathi, A. and Surendra, T.V. (2013) Low-Cost and Eco-Friendly Phyto-Synthesis of Silver Nanoparticles Using Cocos nucifera Coir Extract and Its Larvicidal Activity. Industrial Crops and Products, 43, 631-635. https://doi.org/10.1016/j.indcrop.2012.08.013

[34] Joy Prabu, H. and Johnson, I. (2015) Plant-Mediated Biosynthesis and Characterization of Silver Nanoparticles by Leaf Extracts of Tragia involucrata, Cymbopogon citronella, Solanum verbascifolium and Tylophora ovate. Karbala International Journal of Modern Science, 1, 237-246. https://doi.org/10.1016/j.kijoms.2015.12.003 
[35] Dong, C., Zhang, X. and Cai, H. (2014) Green Synthesis of Monodisperse Silver Nanoparticles Using Hydroxy Propyl Methyl Cellulose. Journal of Alloys and Compounds, 583, 267271. https://doi.org/10.1016/j.jallcom.2013.08.207

[36] Mohammadlou, M., Maghsoudi, H. and Jafarizadeh-Malmiri, H. (2015) A Review on Green Silver Nanoparticles Based on Plants: Synthesis, Potential Applications and Eco-Friendly Approach. International Food Research Journal, 23, 446-463.

[37] Khatami, M., Pourseyed, S., Khatami, M., Hamidi1, H., Zaeifi, M. and Soltani, L. (2015) Synthesis of Silver Nanoparticles Using Seed Exudates of Sinapis arvensis as a Novel Bioresource, and Evaluation of Their Antifungal Activity. Bioresources and Bioprocessing, 2, 19. https://doi.org/10.1186/s40643-015-0043-y

[38] Hungund, B.S., Dhulappanavar, G.R. and Ayachit, N.H. (2015) Comparative Evaluation of Antibacterial Activity of Silver Nanoparticles Biosynthesized Using Fruit Juices. Journal of Nanomedicine and Nanotechnology, 6, 271. https://doi.org/10.4172/2157-7439.1000271

[39] Thomas, R., Janardhanan, A., Varghese, R.T., Soniya, E.V., Mathew, J. and Radhakrishnan, E.K. (2014) Antibacterial Properties of Silver Nanoparticles Synthesized by Marine Ochrobactrum sp. Brazilian Journal of Microbiology, 45, 1221-1227. https://doi.org/10.1590/S1517-83822014000400012

[40] Chitra, K. and Annadurai, G. (2014) Antibacterial Activity of pH-Dependent Biosynthesized Silver Nanoparticles against Clinical Pathogen. BioMed Research International, 2014, Article ID: 725165.

[41] Balashanmugam, P. and Kalaichelvan, P.T. (2015) Biosynthesis Characterization of Silver Nanoparticles Using Cassia roxburghii DC. Aqueous Extract, and Coated on Cotton Cloth for Effective Antibacterial Activity. International Journal of Nanomedicine, 10, 87-97. https://doi.org/10.2147/IJN.S79984

[42] Paredes, D., Ortiz, C. and Torres, R. (2014) Synthesis, Characterization, and Evaluation of Antibacterial Effect of Ag Nanoparticles against Escherichia coli O157:H7 and Methicillin-Resistant Staphylococcus aureus (MRSA). International of Journal Nanomedicine, 9, 1717-1729.

[43] Nasim, K. and Asghar, T. (2014) Antibacterial Effect of Silver Nanoparticles on Acinetobacter Baumannii. Iranian Journal of Public Health, 43, 39.

[44] Singh, K., Panghal, M., Kadyan, S., Chaudhary, U. and Yadav, J.P. (2014) Antibacterial Activity of Synthesized Silver Nanoparticles from Tinospora cordifolia against Multi Drug Resistant Strains of Pseudomonas aeruginosa Isolated from Burn Patients. Journal of Nanomedicine and Nanotechnology, 5, 2. https://doi.org/10.4172/2157-7439.1000192

[45] Wu, D., Fan, W., Kishen, A., Gutmann, J.L. and Fan, B. (2014) Evaluation of the Antibacterial Efficacy of Silver Nanoparticles against Enterococcus faecalis Biofilm. Journal of Endodontics, 40, 285-290. https://doi.org/10.1016/j.joen.2013.08.022

[46] Tamayo, L.A., Zapata, P.A., Vejar, N.D., Azocar, M.I., Gulppi, M.A., Zhou, X., Thompson, G.E., Rabagliati, F.M. and Paez, M.A. (2014) Release of Silver and Copper Nanoparticles from Polyethylene Nanocomposites and Their Penetration into Listeria monocytogenes. Materials Science and Engineering: C, 40, 24-31. https://doi.org/10.1016/j.msec.2014.03.037

[47] Collins, T.L., Markus, E.A., Hassett, D.J. and Robinson, J.B. (2010) The Effect of a Cationic Porphyrin on Pseudomonas aeruginosa Biofilms. Current Microbiology, 61, 411-416. https://doi.org/10.1007/s00284-010-9629-y

[48] Bankalgi, S.C., Londonkar, R.L., Madire, U. and Tukappa, N.K.A. (2016) Biosynthesis, Characterization and Antibacterial Effect of Phenolics-Coated Silver Nanoparticles Using Cassia javanica L. Journal of Cluster Science, 27, 1485-1497. https://doi.org/10.1007/s10876-016-1016-9

[49] Van Dong, P., Ha, C.H., Binh, L.T. and Kasbohm, J. (2012) Chemical Synthesis and Anti- 
bacterial Activity of Novel-Shaped Silver Nanoparticles. International Nano Letters, 2, 9. https://doi.org/10.1186/2228-5326-2-9

[50] Panacek, A., Smekalova, M., Kilianova, M., Prucek, R., Bogdanova, K., Večeřová, R., et al. (2015) Strong and Nonspecific Synergistic Antibacterial Efficiency of Antibiotics Combined with Silver Nanoparticles at Very Low Concentrations Showing No Cytotoxic Effect. Molecules, 21, E26.

[51] Zhang, M., Zhang, K., De Gusseme, B., Verstraete, W. and Field, R. (2014) The Antibacterial and Anti-Biofouling Performance of Biogenic Silver Nanoparticles by Lactobacillus fermentum. Biofouling, 30, 347-357. https://doi.org/10.1080/08927014.2013.873419

Submit or recommend next manuscript to SCIRP and we will provide best service for you:

Accepting pre-submission inquiries through Email, Facebook, LinkedIn, Twitter, etc. A wide selection of journals (inclusive of 9 subjects, more than 200 journals) Providing 24-hour high-quality service User-friendly online submission system Fair and swift peer-review system Efficient typesetting and proofreading procedure Display of the result of downloads and visits, as well as the number of cited articles Maximum dissemination of your research work

Submit your manuscript at: http://papersubmission.scirp.org/ Or contact jbnb@scirp.org 